\title{
Derivatives Usage: Value-Adding Or Destroying?
}

John Naito, Colorado College, USA

Judy Laux, Colorado College, USA

\begin{abstract}
The following article tests the wealth-building nature of derivatives usage in non-financial firms. Investigating 434 firms and employing univariate and multivariate tests, it uses both the fair values and notional values of firms' derivatives contracts to determine whether derivatives usage enhances or destroys firm value.
\end{abstract}

Keywords: Derivatives; Risk Management; Stockholder Wealth; Agency Theory

\section{INTRODUCTION}

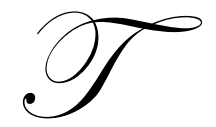

he large and ever-increasing number of firms using derivative instruments invites the question: does derivative usage add value to the firm? At the heart of this question is the presumed professional and ethical duty of financial management, stockholder wealth maximization. This study investigates the relationship between firm value and derivative usage by non-financial firms.

According to Modigliani and Miller's capital structure irrelevance principle, the value of a firm is independent of its risk management policies and behavior. However, the capital structure irrelevance principle only stands in the absence of frictions (noise) in an efficient market (wherein all available information is known by the investor). When real world frictions such as asymmetric information, bankruptcy costs, taxes, and costly external financing are introduced, the perfect market on which the Modigliani and Miller model depends disappears, and the door is opened for value-adding risk management policy. Among these frictions, derivative instruments possess the opportunity to add value.

This study is presented in two sections. The first section reviews relevant literature, including theoretical and empirical research on the determinants of firms' hedging policies and empirical research on the real value effect of derivatives hedging policies. The second section presents the empirical research conducted by this study, including univariate and multivariate tests of both the fair values and notional values of firms' derivative contracts.

\section{REVIEW OF RELEVANT LITERATURE}

Early research on derivative usage as a hedging option focuses on the frictions that allow derivatives to add value. Both theoretical and empirical research has been published on the reasons why firms choose to hedge using derivatives. Smith and Stulz's 1985 paper stands among the early literature on the subject. Using mathematical models, the authors find that by reducing the variability of pre-tax firm value, derivative hedging can increase the after-tax value of the firm if the transaction costs of the derivatives employed are less than the increase in value. They also find that, by reducing the future variability of firm value, derivative usage can decrease the expected costs of bankruptcy.

Adding to the literature on the incentives for hedging, Bessembinder [1991] finds that derivative usage can reduce underinvestment, as follows:

By shifting individual future states from default to nondefault outcomes, hedges increase the proportion of future states in which equity holders are the residual claimants. This reduces the fraction of the benefit from incremental 
investment that accrues to nonequity claimants, thereby reducing incentives for equity holders to underinvest. ( $\mathrm{p}$. 531)

Bessembinder also discovers that the use of derivative hedging (especially continual hedging) can increase the contract terms of the firm's debt. Extending Bessembinder's findings, Leland [1998] reveals that derivatives allow a firm to increase its debt capacity. He concludes that while equity holders lose value to bond holders by increasing a firm's leverage through derivatives hedging, the increased debt provides income-increasing tax benefits that more than offset the value lost to bond holders. Finally, DeMarzo and Duffie [1995] theorize that hedging policies reduce noise, thereby allowing investors to make better portfolio decisions with regard to risk management. In addition to the body of theoretical research on the incentives for firms to hedge with derivatives, a substantial amount of empirical work on the subject also exists.

Of the empirical research on hedging incentives, some studies support theory while others reject it. Continuing Smith and Stulz's theoretical work on reducing financial distress costs, Purnanandam [2008] studies a sample of 2,256 non-financial, non-utility firms, finding that financially distressed firms, in highly concentrated industries, do, in fact, hedge more. Geczy et al. [1997], in their study of 372 of the Fortune 500 non-financial firms in 1990 find that higher quick ratios (a measure of immediately available internal funds) are associated with a lower probability of hedging. The study also finds that firms with more growth opportunities (as reflected through greater R\&D expense) have an increased probability of hedging. This suggests that hedging is used to ensure the availability of internal funds for future projects, especially when the firm is financially constrained. Contrary to most literature in the field, Bartram et al. [2009] reject many of the derivative usage determinant theories. Their results do not support the underinvestment hypothesis ( $\&$ D and capital expenditures are negatively correlated with hedging) nor the financial distress hypothesis (derivative users are found to be larger and more profitable than nonusers). They suggest that previous research lacks the power of their study, which includes 7,319 non-financial firms, a sample that "covers about $80 \%$ of global market capitalization of nonfinancial firms" (p. 186). While a plethora of research exists on the determinants of firm's hedging policies, and how the use of derivatives can increase firm value, not until recently has research been conducted on how derivative usage affects firm value.

Only a few studies take the determinants of firms' hedging policies one step further and investigate whether or not a firm's decision to hedge increases its value. In a study conducted by Allayannis and Weston [2001], a sample of 720 non-financial firms exposed to foreign exchange rate risk is analyzed using Tobin's $Q$ as a measure of firm value. The results suggest that firm value is related positively to derivative usage with a 4.87 percent premium placed on hedging. Nelson et al. [2005] examine stock price performance and derivative usage for over 5770 firms. The results support the hypothesis that firms that hedge using derivatives are valued higher (stock price performs 4.3 percent per year on average better than that of firms that don't use derivatives). However, they also find that the increased performance is driven largely by currency derivatives. In fact, currency derivatives are the only type of hedge that produces gains for the firm. Pramborg [2004] analyzes foreign exchange exposure specifically for Swedish non-financial firms and finds that hedging transaction exposure is value-adding, while hedging translation exposure is not. Graham and Rogers [2002], in investigating tax incentives for corporations to hedge, find that derivatives increase a firm's debt ratio by an average of 3 percent, which contributes to a 1.1 percent increase in firm value (in the form of tax shields). Adam and Fernando [2006] find that derivative hedging by gold and silver mining companies increases the firms' cash flows. Because the increased cash flows are not met with a greater risk exposure, the derivative usage has a positive effect on firm value. The study also finds that "selective hedging," in which managers slip some speculation into their "hedging" strategy, provides a significant increase in cash flows. Carter, Rogers, and Simkins [2006], in a study of 28 airlines, find that hedging jet fuel prices using derivative contracts has a positive effect on firm value. The study finds a hedging premium of between five and ten percent, which it largely attributes to the increase in availability of internal funds for investment opportunities. Finally, Clark and Judge [2009] study a sample of 412 non-financial firms ranked in the top 500 firms in the UK based on market value at year-end 1995. They find that when foreign currency (FC) derivatives are employed, either as the sole FC risk management tool or in conjunction with $\mathrm{FC}$ debt, they are value enhancing.

Hagelin, Holmén, Knopf, and Pramborg [2007] and Jin and Jorion [2006] continue the research into the value effect of derivatives but find inconclusive (statistically insignificant) results. Hagelin et al. perform three tests: an ordinary least squares (OLS) regression, a Treatment Effects regression, and a two-stage least squares 
(2SLS) regression. While all three tests return a positive correlation between hedging and firm value, only the OLS and Treatment Effects regressions contain statistically significant results. Jin and Jorion find dissimilar results. Their study of 119 U.S. oil and gas producers finds that, while derivative usage is successful in reducing the sensitivity of stock prices to oil and gas prices, it does not increase firm value. To the contrary, most of the tests result in a negative relationship between derivative usage and firm value. While none of these results is statistically significant, other studies have shown a statistically significant negative value effect for derivative usage.

Nguyen and Faff [2010], find that hedging interest rates with derivatives has a negative impact on firm value. However, in their study of 428 Australian firms, the authors cannot suggest with statistical significance that foreign currency derivatives or commodities derivatives affect firm value. Ben Khediri [2010], in a sample of 250 non-financial French firms from 2000 to 2002, finds similar results to those of Nguyen and Faff. The study finds that the decision to use any type of derivative for hedging purposes is associated with a 26.3 percent lower market value (significant at the ten percent level). Ben Khediri attributes the results to the difference in analyst and investor perceptions regarding derivative usage in France compared to those in the U.S. While much of the empirical research on the question of how derivative usage affects the value of non-financial firms suggests a positive relationship, the question is by no means answered. As seen above, some of the most recent literature suggests that derivative usage has a negative effect on firm value. The current paper expands the literature with an analysis of the effects of derivative usage on firm value in a more contemporary sample of non-financial firms.

\section{DATA \& METHODOLOGY}

The sample data set for this study includes the S\&P 500 from February 2011. The S\&P 500 represents a broad-based index that is generally considered a reasonably accurate spread of U.S. firms across industries. Financial depository institutions, financial nondepository institutions, and securities and commodities brokers are excluded, as they are outside the scope of this study. The distinction between financial and non-financial firms was determined by companies' primary two-digit SIC codes. Thirty banks and fourteen securities and commodities brokers were excluded. Firms that were on the S\&P 500 in February 2011 but that did not have a 2009 annual report in the MergentOnline database were also excluded. This amounted to eleven firms. In total, 434 firms are included in the main sample. Thirty-four firms were removed from the sample used in the notional values tests due to a lack of data in the firms' annual reports, resulting in a total sample size of 400 for those tests.

Of the 434 firms, 328 firms (75.6\%) use derivative instruments (24.4\% do not use derivatives). Of those 328 firms, 88 use only derivatives designated as hedges (27\% of derivative users) and 66 use only derivatives not designated as hedges (19\% of derivative users); 179 firms use both derivatives designated and not designated as hedges (54\% of all derivative users).

This study tests whether derivative usage by non-financial firms is significantly related to firm value using univariate tests and multivariate regression models. Univariate tests find both the mean and median a modified Tobin's Q (defined below and using book value rather than replacement cost) for firms that do not use derivatives (non-users), firms that use only derivatives designated as hedging instruments (designated users), firms that use only derivatives not designated as hedging instruments (non-designated users), and all firms that use derivatives (users). These tests use the fair value of firms' derivative usage rather than the notional value of derivative usage as the use of fair value data allows for the separation of designated users from non-designated users and includes a larger sample (434 observations versus 400).

The data are further investigated using an ordinary least squares (OLS) estimator. Firm value is regressed against derivative usage (FV against DERX). This gives the simple univariate regression equation,

EQ1: $\quad \mathrm{FV}_{\mathrm{i}}=\mathrm{C}+\mathrm{A}\left(\mathrm{DERX}_{\mathrm{i}}\right)+\mathrm{e}$

where $\mathrm{C}$ is a constant and the vertical axis intercept; $\mathrm{FV}_{\mathrm{i}}$, is firm value for any given value, $\mathrm{i}$, expressed as (Market Value of Equity + Book Value of Liabilities) divided by (Book Value of Equity + Book Value of Liabilities);DERX is derivative usage for any given value, $\mathrm{i} ; \mathrm{A}$ is the regression coefficient of $\mathrm{DERX} \mathrm{X}_{\mathrm{i}}$, and e represents the error term. The above equation, however, ignores many variables that can affect a firm's $Q$ ratio. As previously mentioned, 
these variables include size of the firm (SIZE), leverage ratio (LEV), profitability (ROA), investment growth opportunities (ING), dividend payments (DIV), geographic diversification (GEO), and industrial diversification (IND). The following regression equation controls for each of these variables:

EQ2: $\quad \mathrm{FV}_{\mathrm{i}}=\mathrm{C}+\mathrm{A}\left(\mathrm{DERX}_{\mathrm{i}}\right)+\mathrm{B}\left(\mathrm{SIZE}_{\mathrm{i}}\right)+\mathrm{D}\left(\mathrm{LEV}_{\mathrm{i}}\right)+\mathrm{E}\left(\mathrm{ROA}_{\mathrm{i}}\right)+\mathrm{F}\left(\mathrm{ING}_{\mathrm{i}}\right)+\mathrm{G}\left(\mathrm{DIV}_{\mathrm{i}}\right)+\mathrm{H}\left(\mathrm{GEO}_{\mathrm{i}}\right)+\mathrm{I}\left(\mathrm{IND}_{\mathrm{i}}\right)$ $+\mathrm{e}$

where A, B, D, E, F, G, H, and I are regression coefficients. EQ2 is the general regression equation used in Models N, A, B, C, D, and E where DER, DERH, DERN, DERT, DERA, and DERL replace DERX, respectively.

Each of the regression models used in this study follows the format of EQ2 but replaces DERX with a different proxy for derivative usage. These proxies along with a description of the control variables can be found in Table 1 (All tables appear at the end of the article). A positive relationship is expected between DERX and FV in all models. That is to say, it is expected that derivative usage by non-financial firms will have a positive effect on firm value.

\section{RESULTS AND ANALYSIS}

\section{Univariate Tests}

The univariate tests return surprising results, all significant at a $10 \%$ level; these are presented in Table 2 . The average Tobin's $\mathrm{Q}$ of non-users is higher than that of users. This is true for both the smaller sample related to the notional values of derivatives and the larger sample related to the fair value of derivatives. The larger sample is the focus of the following description and analysis. The mean Tobin's $Q$ for derivative users is 1.84, while the mean Tobin's Q for non-users is 2.11. This result supports the null hypothesis and suggests that the market discounts derivative usage by non-financial firms. The median Tobin's $Q$ for derivative users and non-users also supports a discount for derivative usage. The medians suggest a $15.1 \%$ premium for non-users over users, or a $13 \%$ discount for derivative usage versus non-usage.

While the univariate tests suggest that derivatives are value-destroying for non-financial firms, they also suggest that a premium is placed on hedging derivatives over non-hedging. Both the median and mean Tobin's Q of firms that account for all of their derivatives as hedging instruments are higher than those of firms that account for all of their derivatives as non-hedges. Between these two groups sits the mean and median Tobin's Q values of firms that designate derivatives as both hedges and non-hedges. This suggests that (1) designating derivatives as hedges is an effective signal to the market (as is not designating derivatives as hedges) and (2) the market values the designation of derivatives as hedging instruments. The univariate tests do not account for variables other than derivative usage that are known to affect firm value. For this reason, univariate tests are only used in a preliminary manner and are reported here because of the interesting implications of their results.

\section{Multivariate Tests}

The multivariate tests of the notional values of firms' derivative contracts return results contrary to those of the corresponding univariate test. The multivariate tests, in general, support a positive relationship between the volume of derivative usage and firm value. The positive coefficient for the DER variable, however, falls just outside the $10 \%$ level with a P-value of .12. The results of Regression Model N are presented in Table 3. To control for possible industry effects, the study includes dummy variables for industries (using two-digit SIC codes) in Regression Model N. The results are similar to those of the original Model $\mathrm{N}$ with no industry variables contributing to firm value with statistical significance. As a robustness test, the top five and bottom five percent of Tobin's Q values are excluded from Model N. The test returns results similar to those of the entire sample and are similarly statistically insignificant.

The multivariate tests for the fair values of firms' derivative contracts return results similar to those of the corresponding univariate tests. The multivariate tests of each derivative usage variable (DERD, DERN, and DERT) suggest a negative relationship between derivative usage as proxied by fair value and firm value. All results are significant at the $1 \%$ level. [See Table 4 for the pertinent regression results of regression models A, B, 
and $\mathrm{C}$, respectively]. Firms that use only derivatives designated as hedges are associated with the greatest decrease in value, followed by firms using only derivatives not designated as hedges. These results are contrary to those of the univariate tests in which designated hedging derivatives were valued higher than non-designated hedging derivatives. Firms using derivatives regardless of designation are associated with the smallest decrease in value.

The fair value of derivative usage was originally included in this study as a proxy for the magnitude of derivative usage by non-financial firms. It was thought that, in the aggregate, the fair value of contracts would be proportional to the volume of derivatives usage. It is now clear that this assumption cannot be made. The fair value of derivative instruments is, however, a proxy for the position of a firm's derivative contracts as it is determined by the price difference between the face value of the contract and the underlying asset. This, in turn, proxies for the outcomes of a firm's risk exposure. A firm that has a high gross fair value (relative to the size of the firm) was exposed to risk that provided extreme (and unwanted) outcomes. The prices of the underlying assets of the firm's derivative contracts deviated from what it had predicted. Analyzing regression models A, B, and C with this interpretation of fair values suggests that the market penalizes a firm's value for risk exposure that results in extreme outcomes.

The possibility also exists that the market discounts /values the position of contracts (asset or liability) as opposed to unpredicted outcomes provided by the hedged risk. To test this theory, the study divides the fair value of derivative contracts into those in asset positions and those in liability positions. The general regression model is then used to test the relationship between derivative contracts in asset positions and firm value and derivative contracts in liability positions and firm value. Both tests result in a negative significant relationship. While the coefficient of the asset position variable is smaller than that of the liability position variable, the confidence intervals are very similar (at the $95 \%$ level); thus the market does not distinguish between derivatives in an asset position versus those in a liability position in determining firm value. This suggests that investors do not discount firm value based on the position of its derivative contracts, which further suggests that investors do not value speculative derivative usage by non-financial firms.

The four multivariate regression models $(\mathrm{N}, \mathrm{A}, \mathrm{B}$, and $\mathrm{C})$ return similar results for control variables. As expected, profitability (ROA) is positively and significantly related to firm value. Size is negatively and significantly related to firm value. This result was also expected and follows Allayannis and Weston [2001], Pramborg [2004], and Ben Khediri [2010]. Dividend payments are negatively and significantly related to firm value. This result suggests that investors do not value dividends as a sign from management that the firm is performing well. One possible reason for the negative relationship is that dividend payments signal a lack of investing opportunities. A positive relationship between investment growth opportunities and firm value would have supported this theory; however the regression models do not return statistically significant results for the investment opportunities variable.

The remaining control variables do not demonstrate statistically significant relationships with firm value. The models return a negative coefficient for ING (investing growth opportunities); however the relationship is not statistically significant. The unknown relationships between industrial diversification and firm value and geographic diversification and firm value merely support the mixed results found in the literature. In all three models leverage is negatively related to firm value as is expected but, again, these results are not statistically significant.

\section{CONCLUSION}

The research question of this paper was left largely unanswered due to a lack of statistically significant results concerning the notional value of derivative contracts. The power of these tests could be increased by increasing the size of the sample. This study could also be improved by separating firms that are not exposed to risks that can be mitigated with derivative instruments from the sample. These firms are neither valued nor devalued based on their non-usage of derivatives.

While it was the aim of this paper to expand the empirical research on this question, it cannot contribute any statistically significant results. This paper does, however, contribute to a relatively unexplored question: does the position of a non-financial firm's derivative contracts affect the value of the firm. Concerning this question, there is plenty of room for further exploration. 
This study suggests that the market values non-financial firms whose derivative contracts have low fair values. Derivative contracts with low fair values suggest that, while the firm was exposed to risks and those risks were hedged with derivative contracts, they did not provide the firm with "extreme" outcomes. Uneventful or temperate outcomes include commodity prices, interest rates, foreign currency exchange rates, etc., moving in close proximity to a firm's derivative contracts. Extreme outcomes occur when the prices of the underlying assets of derivative contracts do not move in close relation to the contract price. This study suggests that the former is valueenhancing and the latter value-destroying. The most important implication that arises from this conclusion is that derivative usage may be less relevant than previous research has suggested. Derivative instruments are used to manage risk exposure caused by price fluctuations of a specific asset. The effectiveness of a derivative hedging contract is measured by the net gain/loss to the firm. The closer the net gain/loss is to zero, the more effective the derivative contract. According to theory, regardless of the outcome of the underlying asset, the market should value the derivative contract based on its effectiveness. This paper suggests otherwise. The outcomes of a firm's risk exposure affect the value of the firm, and the hedging techniques used to mitigate that exposure are potentially ignored.

\section{AUTHOR INFORMATION}

John (Jack) Naito is a 2011 Economics graduate from Colorado College whose senior thesis provided the basis for this work.

Judy Laux is a Gerald L. Schlessman Professor of Economics and Business at Colorado College, teaching and researching in the areas of accounting and finance. The author wishes to thank the Chapman Foundation for funding support for the current series. E-mail: jlaux@ coloradocollege.edu

\section{REFERENCES}

1. Adam, Tim R. and Chitru S. Fernando. "Hedging, speculation, and shareholder value," Journal of Financial Economics 81, no. 2 (08), 2006.

2. Allayannis, George S. and James P. Weston. 2001. "The Use of Foreign Currency Derivatives and Firm Market Value." Review of Financial Studies 14, no. 1 (Spring).

3. Bartram, Sö, Gregory W. Brown, and Frank R. Fehle. 2009. "International Evidence on Financial Derivatives Usage." Financial Management (Blackwell Publishing Limited) 38, no. 1 (Spring): 185-206.

4. Ben Khediri, Karim. 2010. "Do Investors Really Value Derivatives Use? Empirical Evidence From France." Journal of Risk Finance (15265943) 11, no. 1 (01): 62-74.

5. Bessembinder, Hendrik. 1991. "Forward Contracts and Firm Value: Investment Incentive and Contracting Effects." Journal of Financial \& Quantitative Analysis 26, no. 4 (12): 519-532.

6. Carter, David A., Daniel A. Rogers, and Betty J. Simkins. "Hedging and Value in the U.S. Airline Industry," Journal of Applied Corporate Finance 18, no. 4 (11), 2006.

7. Clark, Ephraim and Amrit Judge. 2009. "Foreign Currency Derivatives versus Foreign Currency Debt and the Hedging Premium." European Financial Management 15, no. 3 (06): 606-642.

8. DeMarzo, Peter M. and Darrell Duffie. 1995. "Corporate Incentives for Hedging and Hedge Accounting." Review of Financial Studies 8, no. 3 (Fall): 743-771.

9. Géczy, Christopher, Bernadette A. Minton, and Catherine Schrand. 1997. "Why Firms Use Currency Derivatives." Journal of Finance 52, no. 4 (09): 1323-1354.

10. Graham, John R. and Daniel A. Rogers. 2002. "Do Firms Hedge in Response to Tax Incentives?" Journal of Finance 57, no. 2 (04): 815-839.

11. Hagelin, Niclas, Martin Holmén, John D. Knopf, and Bengt Pramborg. 2007. "Managerial Stock Options and the Hedging Premium." European Financial Management 13, no. 4 (09): 721-741.

12. Jin, Yanbo and Philippe Jorion. 2006. "Firm Value and Hedging: Evidence from U.S. Oil and Gas Producers." Journal of Finance 61, no. 2 (04): 893-919.

13. Leland, Hayne E. 1998. "Agency Costs, Risk Management, and Capital Structure." Journal of Finance 53, no. 4 (08): 1213-1243.

14. Nelson, James M., Jacquelyn S. Moffitt, and John Affleck-Graves. 2005. "The Impact of Hedging on the Market Value of Equity.” Journal of Corporate Finance 11, no. 5 (10): 851-881. 
15. Nguyen, Hoa and Robert Faff, "Does the Type of Derivative Instrument Used by Companies Impact Firm Value" Applied Economics Letters Vol. 17 Issue 7, 2010: 681-683.

16. Pramborg, Bengt. 2004. "Derivatives Hedging, Geographical Diversification, and Firm Market Value." Journal of Multinational Financial Management 14, no. 2 (04): 117-133.

17. Purnanandam, Amiyatosh. 2008. "Financial Distress and Corporate Risk Management: Theory and Evidence." Journal of Financial Economics 87, no. 3 (03): 706-739.

18. Smith, Clifford W. and René M. Stulz. 1985. "The Determinants of Firms' Hedging Policies." Journal of Financial \& Quantitative Analysis 20, no. 4 (12): 391-405. 
Table 1

Variable Descriptions And Formulas

\begin{tabular}{|c|c|c|c|}
\hline \multicolumn{4}{|r|}{ riptions And Formula } \\
\hline Variable & $\begin{array}{c}\text { Type of } \\
\text { variable }\end{array}$ & Description & Formula \\
\hline \multirow{2}{*}{ DER } & \multirow{2}{*}{ IV } & \multirow{2}{*}{$\begin{array}{l}\text { Notional value of } \\
\text { derivatives (total) }\end{array}$} & total notional value of derivative instruments \\
\hline & & & total assets \\
\hline DERD & IV & $\begin{array}{l}\text { Fair value of derivatives } \\
\text { designated as hedging } \\
\text { instruments }\end{array}$ & $\begin{array}{c}\text { total fair value of derivatives } \\
\text { designated as hedging instruments }\end{array}$ \\
\hline \multirow[t]{2}{*}{ DERN } & \multirow[t]{2}{*}{ IV } & $\begin{array}{l}\text { Fair value of derivatives } \\
\text { not designated as }\end{array}$ & $\begin{array}{l}\text { total fair value of derivatives not } \\
\text { designated as hedging instruments }\end{array}$ \\
\hline & & hedging instruments & total assets \\
\hline DERT & IV & $\begin{array}{c}\text { Fair value of all } \\
\text { derivatives (total) }\end{array}$ & DERD + DERN \\
\hline DERA & IV & $\begin{array}{l}\text { Fair value of asset } \\
\text { derivatives }\end{array}$ & $\frac{\text { total fair value of asset derivatives }}{\text { total assets }}$ \\
\hline \multirow{2}{*}{ DERL } & \multirow{2}{*}{ IV } & \multirow{2}{*}{$\begin{array}{c}\text { Fair value of liability } \\
\text { derivatives }\end{array}$} & total fair value of liability derivatives \\
\hline & & & total assets \\
\hline \multirow{2}{*}{$\mathrm{FV}$} & \multirow{2}{*}{ DV } & \multirow{2}{*}{ Firm value, or Tobin's Q } & market value of equity + book value of liabilities \\
\hline & & & book value of equity + book value of liabilities \\
\hline \multirow{2}{*}{ ROA } & \multirow{2}{*}{$\mathrm{CV}$} & \multirow{2}{*}{ Profitability } & net income \\
\hline & & & $\overline{\text { total assets }}$ \\
\hline \multirow{2}{*}{ GEO } & \multirow{2}{*}{$\mathrm{CV}$} & \multirow{2}{*}{$\begin{array}{l}\text { Geographic } \\
\text { diversification }\end{array}$} & foreign sales \\
\hline & & & total sales \\
\hline IND & $\mathrm{CV}$ & Industrial diversification & Number of business segments that contribute to revenue \\
\hline SIZE & $\mathrm{CV}$ & Firm size & $\ln ($ total assets) \\
\hline \multirow{2}{*}{ ING } & \multirow{2}{*}{$\mathrm{CV}$} & \multirow{2}{*}{$\begin{array}{l}\text { Investment growth } \\
\text { opportunities }\end{array}$} & capital expenditures \\
\hline & & & firm market value \\
\hline DIV & $\mathrm{CV}$ & Dividends & $\begin{array}{c}\text { Dummy variable: } 1 \text { if dividends paid during } 20090 \text { if no dividends } \\
\text { paid during } 2009\end{array}$ \\
\hline \multirow{2}{*}{ LEV } & \multirow{2}{*}{$\mathrm{CV}$} & \multirow{2}{*}{ Leverage } & Long - term Debt \\
\hline & & & Equity \\
\hline
\end{tabular}

*Significant at the $10 \%$ level.

Table 2

Descriptive Statistics From The Univariate Tests Of Fair Values

\begin{tabular}{lcccc}
\hline & \multicolumn{3}{c}{ Tobin's Q } \\
\hline & Non-Users & Designated Users & Non-Designated Users & Users \\
Mean & & & & $1.6596^{*}$ \\
Standard Error & $2.1140^{*}$ & $2.0213^{*}$ & 0.1216 & $1.8393^{*}$ \\
Median & 0.1060 & 0.1174 & $1.4431^{*}$ & 0.0541 \\
Standard Deviation & $1.7516^{*}$ & $1.6455^{*}$ & 0.9504 & $1.5213^{*}$ \\
Sample Variance & 1.0914 & 1.1013 & 0.9032 & 0.9811 \\
Count & 1.1913 & 1.213 & 61 & 0.9626 \\
\hline
\end{tabular}

*Significant at the $10 \%$ level. 
Table 3

Results Of Regression Model N (Notional Value Of Derivative Instruments)

\begin{tabular}{|c|c|c|c|c|c|}
\hline Source & SS & df & MS & Number of obs & 400 \\
\hline \multirow{2}{*}{$\begin{array}{l}\text { Model } \\
\text { Residual }\end{array}$} & 197.097 & 8 & 24.63712 & $\mathrm{~F}(8,425)$ & 41.02 \\
\hline & 234.8187 & $3.91 \mathrm{E}+02$ & 0.600559 & Prob $>$ F & 0 \\
\hline \multirow[t]{2}{*}{ Total } & \multirow[t]{2}{*}{431.9157} & \multirow[t]{2}{*}{399} & \multirow[t]{2}{*}{1.082496} & R-squared & 0.4563 \\
\hline & & & & $\begin{array}{l}\text { Adj R-squared } \\
\text { Root MSE }\end{array}$ & $\begin{array}{c}0.4452 \\
0.77496\end{array}$ \\
\hline
\end{tabular}

\begin{tabular}{c|cccccc}
\hline FV & Coef. & Std. Err. & $\mathbf{t}$ & P>t & [95\% Conf. & Interval] \\
\hline DER & $2.79 \mathrm{E}-06$ & $1.79 \mathrm{E}-06$ & 1.56 & 0.12 & $-7.30 \mathrm{E}-07$ & $6.31 \mathrm{E}-06$ \\
ROA & 0.082621 & 0.0065 & 12.71 & 0 & 0.069842 & 0.095400 \\
GEO & 0.166263 & 0.145588 & 1.14 & 0.254 & -0.11997 & 0.452497 \\
IND & -0.01533 & 0.020041 & -0.76 & 0.445 & -0.05473 & 0.024076 \\
SIZE & -0.23987 & 0.036845 & -6.51 & 0 & -0.31231 & -0.16744 \\
ING & 0.141552 & 0.217353 & 0.65 & 0.515 & -0.28577 & 0.568879 \\
DIV & -0.10375 & 0.09522 & -1.09 & 0.277 & -0.29096 & 0.083453 \\
LEV & -0.00091 & 0.002511 & -0.36 & 0.717 & -0.00585 & 0.004025 \\
_cons & 6.949316 & 0.850161 & 8.17 & 0 & 5.277857 & 8.620775 \\
\hline
\end{tabular}

Table 4

Partial Results Of Regression Models A, B, And C

Number of obs

434

\begin{tabular}{c|cccccc}
\hline FV & Coef. & Std. Err. & t & P>t & [95\% Conf. & Interval] \\
\hline DERD & -2218.76 & 808.7347 & -2.74 & 0.006 & -3808.38 & -629.144 \\
DERN & -741.407 & 200.7858 & -3.69 & 0 & -1136.06 & -346.750 \\
DERT & -609.161 & 166.9997 & -3.65 & 0 & -937.409 & -280.913 \\
\hline
\end{tabular}


Journal of Business \& Economics Research - November 2011

\section{NOTES}

